\title{
Fluvial braidplain to shallow marine transition in the early Neoproterozoic Morar Group, Fannich Mountains, northern Scotland
}

\author{
H. C. Bonsor ${ }^{(\mathrm{a})}$, R. A. Strachan ${ }^{(\mathrm{b})}$, A. R. Prave ${ }^{(\mathrm{c})}$ and M. Krabbendam ${ }^{(\mathrm{a})}$ \\ (a) British Geological Survey, Murchison House, West Mains Road, Edinburgh, EH9 3LA, \\ UK, (email: helnso@bgs.ac.uk) \\ (b) School of Earth and Environmental Sciences, University of Portsmouth, Portsmouth, PO1 \\ $3 Q L, U K$ \\ (c) Geosciences, University of St Andrews, St Andrews, KY16 9AL, UK,
}

\begin{abstract}
The early Neoproterozoic Morar Group in northern Scotland forms the lower part of the Moine Supergroup, deformed and metamorphosed within the Precambrian Knoydartian and Lower Palaeozoic orogenies. It has remained uncertain whether it was deposited in a shallowmarine 'failed rift' basin within Rodinia or a foreland basin on the margin of the Grenville Orogen, which is important to determine for tectonic reconstructions. In that context, we assess the sedimentology, depositional environment and tectonic setting of the middle part of the Morar Group in the Fannich Mountains. A c. 4-6 km thick fining-upwards facies succession contains three psammite dominated lithofacies (LF): LF1, at the base, contains amalgamated and multi-storey sets of trough and tabular cross beds, which passes upward into LF2 consisting of trough and tabular cross-bedded units arranged in coarsening-upward sequences with minor pelitic rocks. The stratigraphically highest lithofacies, LF3, contains finer and more complex coarsening-upward packages of rhythmically interbedded pelite and psammite. Palaeoflow develops from broadly unimodal NW-NNE flow in LF1, to weakly bimodal NW-SE flow in LF3. The data indicate that this part of the Morar Group records deposition in a distal fluvial braidplain to tidally influenced shallow-marine setting. All facies and palaeocurrent transitions are gradual and occur systematically over many 100s of metres vertically; such characteristics are incompatible with a rift-basin setting. We suggest that, instead, deposition occurred in a transition between a foreland basin to the Grenville orogen and a marine basin associated with the Asgard Sea between Baltica and Laurentia.
\end{abstract}

Keywords: Neoproterozoic; Sedimentology; Moine; Morar Group; Shallow marine; Braidplain 


\subsection{Introduction}

The amalgamation of Laurentia, Baltica and Amazonia at 1.1-1.0 Ga resulted in the Grenville Orogeny and the assembly of Rodinia (Hoffman 1991; Sadowski \& Bettencourt 1996; Li et al. 2008). The erosion of the Grenville mountain chain during the early Neoproterozoic led to the deposition of thick siliciclastic successions in the present day circum-North Atlantic region (Rainbird et al. 2001; Cawood et al. 2007; Krabbendam et al. 2008; Pettersson et al. 2009). Many of these successions were subsequently deformed at medium to high-grade metamorphic grades during the Precambrian Knoydartian and Lower Palaeozoic Caledonian orogenies, as a result of which it is commonly difficult to reconstruct original depositional settings. In this paper we focus on one of those sequences, the Moine Supergroup of northern Scotland. The tectonic setting of the Moine Supergroup basin(s) depends on the palaeocontinental configuration during the early Neoproterozoic. A setting well within Rodinia was suggested by Dalziel \& Soper (2001) on the basis of a reconstruction that placed Baltica directly opposite East Greenland (Fig 1a). In contrast, a more recent reconstruction places northern Scotland much closer to the margin of Rodinia (Fig 1b; Li et al. 2008; Cawood et al. 2010).

\section{[Figure 1]}

The Moine Supergroup has previously been interpreted as a shallow-marine deposit that accumulated in extensional rift basins (Strachan 1986; Glendinning 1988; Soper et al. 1998). It was suggested by Dalziel \& Soper (2001) that these were intracratonic 'failed rifts' developed in the central part of Rodinia at the same time as the separation of Antarctica from western North America at c.850-800 Ma. Alternatively, Krabbendam et al. (2008) interpreted lower parts of the Moine Supergroup as fluvial, braidplain deposits (see also Bonsor \& Prave 2008) that accumulated in a major foreland basin located along the margin of the developing Grenville orogen. These authors also suggested correlation with the sedimentologically similar Torridon Group that is located on the foreland to the Caledonian orogen in northern Scotland. The discovery of a thick well-preserved stratigraphic succession of the Morar Group in low strain zones in the Fannich Mountains of northern Scotland (Fig 2) provides an opportunity to assess the sedimentology of this hitherto poorly known part of the Moine Supergroup, and thence to examine the implications for regional correlations and the tectonic setting of the depositional basin. 


\section{[Figure 2]}

\subsection{Geological Setting}

The lowest part of the Moine Supergroup is the Morar Group, mainly comprising thick sequences of meta-sandstone (psammite) with subordinate meta-siltstone (semi-pelite) and meta-mudstone (pelite) (Holdsworth et al. 1994). Outcrop of the Morar Group is limited to the west by the Moine Thrust, forming the margin of the Caledonian orogen in Scotland, and to the east by the Sgurr Beag Thrust (Fig. 2). The generally pelitic Glenfinnan Group and psammitic Loch Eil Group occur in the hangingwall of this thrust (Fig. 2). Within both the Morar and Glenfinnan groups, inliers of Archaean Lewisianoid gneiss are thought to represent the basement on which the Moine rocks were deposited (e.g. Peach et al. 1907 Ramsay 1958; Holdsworth 1989; Friend et al. 2008) The Morar Group contains detrital zircons that yield U-Pb ages of between 1.7 and $1.0 \mathrm{Ga}$ (Friend et al. 2003; Kirkland et al. 2008) and these have been interpreted to be derived from Eastern Laurentia (Friend et al. 2003; Cawood et al. 2007; Kirkland et al. 2008) or, more specifically, the Grenville orogen (Krabbendam et al. 2008) . The youngest reliable concordant zircon grains reported from different samples are $1032 \pm 24 \mathrm{Ma}$ (Friend et al. 2003); $1022 \pm 24 \mathrm{Ma}$ (Kirkland et al. 2008) and $980 \pm 2 \mathrm{Ma}$ (D. Peters, pers. comm. in Cawood et al. 2007). The structural and metamorphic complexity of the Moine rocks results from their involvement in Knoydartian (c.820-725 Ma), Grampian (470-460 Ma) and Scandian (435-425 Ma) orogenic events, the latter two of which are part of the Caledonian orogenic cycle (Strachan et al. 2002, 2010; Cutts et al. 2010).

Despite the deformational overprinting, it has proved possible to achieve reasonably detailed sedimentological analysis in areas of low tectonic strain (Glendinning 1988; Bonsor and Prave 2008; Krabbendam et al. 2008). Krabbendam et al. (2008) interpreted the lowermost part of the Morar Group (the Altnaharra Formation) in Sutherland, northern Scotland (Fig. 2) as a fluvial braidplain deposit. Stratigraphically and structurally higher levels of the Morar Group are exposed further south in the Fannich Mountains (Fig. 2). Here, the Altnaharra Formation passes up into, in order, the Glascarnoch, Vaich Pelite, Crom Psammite and Diebidale Pelite formations (Fig. 3; Krabbendam et al. in press). The total thickness of the 
Morar Group is estimated to be c.6.0-9.0 km. In this paper we focus on the sedimentology of the upper Altnaharra and Glascarnoch formations. The succession is deformed on a large scale into major folds, but is internally intact and strain is overall not high, and thus it has proved possible to reconstruct the original pre-deformational stratigraphy (Fig. 4; Krabbendam et al. in press). The stratigraphic succession is characterised by some significant lateral variations: the Altnaharra Formation thins towards the east, whilst the Glascarnoch Formation thickens to the east and forms, in part, its lateral equivalent.

\section{[Figures 3 and 4]}

\subsection{Sedimentology of the middle Morar Group: Altnaharra and Glascarnoch formations}

\subsection{Facies types and architecture}

The Altnaharra and Glascarnoch formations comprise psammites interbedded with varying amounts of pelite. Tectonic deformation was associated with amphibolite-facies metamorphism and recrystallisation which obliterated most of the original grain textures, such as grain shape and sorting, although locally detrital feldspar grains can be recognised. However, larger-scale original sedimentary features of the rocks are well preserved in kmscale low strain zones within the hinge zones of the regional folds (Krabbendam et al. in press). Three main lithofacies are identified: LF1, LF2 and LF3 (Fig. 5). Transitions between these lithofacies are gradual and consistently define a fining-upward succession recognised by an increase in proportion of finer-grained psammites and pelitic lithologies in the younger parts of the succession.

\section{[Figure 5]}

\subsubsection{Lithofacies 1 (LF1): trough cross-bedded psammite.}

LF1 is observed throughout the Glen Achall Member, the uppermost unit of the Altnaharra Formation. Its stratigraphic thickness is approximately $1.5-2 \mathrm{~km}$ and is composed mainly of feldspathic to quartzose psammite, containing c. $65 \%$ quartz, c. $25 \%$ feldspar and c. $10 \%$ mica. The feldspathic composition gives a variable pink hue to the rocks. The micas are 
derived from the metamorphism of clay minerals, however, the quartz-feldspar ratio is unlikely to have been significantly changed by metamorphism.

Psammite constitutes more than $95 \%$ of LF1, with the remainder being pelite. The lithofacies is typified by amalgamated and stacked sets and co-sets of trough cross-beds, 0.05 to $0.6 \mathrm{~m}$ thick. These define wide lens-shaped channel forms, with large width-to-depth ratios (commonly $>15 \mathrm{~m}$ wide and $<0.5 \mathrm{~m}$ thick), and erosive, scalloped bed bases. Tabular cross-beds are less frequent but are of a similar thickness to the trough-cross beds. Planar cross-stratified lenticular and wedge-shaped beds are uncommon, but where observed range from $c .3$ to $5 \mathrm{~m}$ in length and 0.2 to $0.5 \mathrm{~m}$ thick. These preserved bed dimensions are, however, regarded as minimal values due to erosional truncation by overlying beds. No mud-drapes, gravel clasts, or gravel lags have been observed. Soft-sediment deformation is rare, but where observed generally shows pinched cuspate geometry, with greatest deformation towards the bed base. Almost all observed soft-sediment deformation features are truncated by overlying beds. LF1 occurs in 10-20 m thick, fining-upward packages (Fig. 6), each characterised by ripple cross-laminated psammite and minor pelitic beds 1 to $2 \mathrm{~cm}$ thick at the base, and multi-storey trough and tabular cross-beds at the top. Some coarseningupwards facies sequences, of a similar thickness, are also observed.

\section{[Figure 6]}

\subsubsection{Lithofacies 2 (LF2): interbedded cross-bedded psammite and pelite.}

LF2 units develop upwards from LF1 and are observed over a stratigraphic thickness of c. 2 $\mathrm{km}$, within the lower to middle Glascarnoch Formation. LF2 is composed of well developed decametre-scale, fining-and coarsening-upward units, marked by both trough- and planarcross bed sets and lenticular bed geometries (Fig. 7a). In comparison to LF1, beds are thinner (typically 0.02 to $0.3 \mathrm{~m}$ thick), bed bases less scalloped, planar cross-stratified beds are more common, and channel width-to-depth ratios larger ( $>20 \mathrm{~m}$ wide; $<0.5 \mathrm{~m}$ thick) (Fig. $7 \mathrm{~b}$ ). Pelitic beds are more common and are thicker (commonly 1 to $4 \mathrm{~cm}$ thick) than in LF1, so that pelitic lithofacies comprise up to $c$. $30 \%$ of each coarsening-upward unit. There is a greater preservation of fines as mud drapes along the foresets of the bedforms throughout the LF2 units than in LF1. Ripple cross-lamination is also more prevalent within the LF2 facies. The psammitic rocks are generally more mature than in LF1, and typically composed of $c$. 
$65 \%$ quartz, c. $20 \%$ feldspar and c. $15 \%$ mica; the higher mica content resulting in a greyer hue. Convoluted, pinched, cuspate soft-sediment deformation features and slump folds are more common within LF2 than in LF1 and are broadly orientated in the dominant palaeoflow direction. Almost all soft-sediment deformation features are truncated by the overlying beds. [Figure 7]

\subsubsection{Lithofacies 3 (LF3): interbedded, ripple-laminated psammite and pelite.}

LF3 units develop upwards from LF2, and are observed within the upper Glascarnoch Formation over a stratigraphic thickness of 1.5 to $2 \mathrm{~km}$. The LF3 units are composed of decametre-scale coarsening upwards units, c. 3-16 m thick, containing broadly equal proportions of micaceous psammite and pelite beds. Characteristically, LF3 units contain a wide range of ripple-scale bedforms. Each unit has a pelitic base, a gradual upward increase of psammite beds and a predominantly psammititc top (Fig. 8). Concomitant with this upward lithological change is a progressive change of bedform structures. The basal pelitic parts show rhythmic bundles of semi-pelitic and psammitic flaser, wavy, lenticular and pinstripe bedforms (Fig. 9a). The central parts of the units show very thin trough crossbedding and tabular psammitic channel facies with abundant ripple-lamination and muddrapes (Fig. 9b).

[Figures 8 and 9]

The uppermost parts of the LF3 units are predominantly composed of stacked and nested trough, and tabular cross-bed co-sets of micaceous psammite (Fig. 9c). Locally mature quartzite layers (c. $>80 \%$ quartz) occur in these positions. Mud-drapes remain well developed within all bed forms (Fig. 9d), but pelitic beds between individual cross-beds become thinner upwards within each unit. Bed thicknesses increase from $<0.02 \mathrm{~m}$ at the base of the LF3 units, to c. $0.4 \mathrm{~m}$ at the top. All bed geometries define very wide, shallow, planarbased channels, typically $>50 \mathrm{~m}$ wide but only $c .0 .2 \mathrm{~m}$ deep. Sharp, planar bed-base geometries are typical; only the uppermost cross-beds of LF3 units display shallow, scalloped-bed base geometries and lenticular channel forms. 
Flow-reversal ripple forms indicate deposition influenced by bi-directional palaeoflow, in which there was a dominant NW and sub-dominant SE current direction (Fig. 9e). The flow reversal ripple forms appear as lozenge-shaped forms, which are truncated by larger, overlying, ripples. The internal cross laminae of the truncated ripples dip in the opposite direction to the cross laminae of larger overlying ripple forms. The larger ripples reflect the dominant flow direction, whereas a weaker current operating in the opposite direction formed the smaller lozenge-shaped ripples.

Soft-sediment deformation is very common within LF3, particularly within the thick crossbeds in the upper sections of the LF3 units. Convoluted, pinched deformation features, slump folding, and wisp-like flame structures are all observed. As in LF2, the direction of overturning of slump folds is broadly parallel to local palaeoflow directions.

\subsection{Palaeocurrent data}

Palaeoflow measurements were taken from axes of trough cross bedding where they were constrained in three dimensions, as these were the most reliable indicators exposed. Data from planar cross-stratified beds were not used because of the potential for such features to exhibit migration other than in down-flow direction. Similarly, measurements were not used from ripple cross-laminations, as these small bedforms can often reflect the directions of minor flows, unrepresentative of the main sediment transport direction.

The field measurements used were corrected for tectonic tilt along horizontal axes, as the large-scale folds in the vicinity of the analysed sections are broadly cylindrical, with little or no evidence of rotation along vertical axes (Krabbendam et al. in press). The resulting data show that palaeocurrents in LF1 and LF2 (upper Altnaharra to lower Glascarnoch Formation) were directed NW-NE, whilst in LF3 (upper Glascarnoch Formation) palaeocurrents were bimodal, with a dominant NW-NNE current direction, and a weaker SE flow (Fig. 10). This 
transition from a broadly unimodal palaeocurrent direction at the base of the stratigraphy to a bimodal palaeocurrent at the top, is gradual, with no abrupt changes observed.

\section{[Figure 10]}

\subsection{Palaeoenvironmental Interpretation}

The lithofacies define a fining-upward facies succession, from stacked and amalgamated trough-cross bed sets at the base, to much more variable coarsening-upward packages of rhythmically interbedded pelitic and psammitic lithologies at the top (Table 1). Over the same stratigraphic interval, palaeoflow develops upwards from broadly unimodal NW-NE flow, to weakly bimodal NW-SE flow.

\section{[Table 1]}

\subsection{LF1}

The stacked, amalgamated trough-cross beds of LF1 in the upper Altnaharra Formation are interpreted as individual channel forms, and the upward fining and thinning of the stacked trough cross-beds on a metre-scale is inferred to reflect waning flows (Leeder 1999; Allen 1985). The dominance of trough cross-bedding relative to planar cross-stratified beds indicates that the depositing flows were sufficiently strong to support a traction load. However, the absence of gravels, or gravel lags within the channels, and low angle of the foresets within the cross beds suggest that flow was only of moderate energy (Kleinhaus 2001; Leeder 1999; Bridge 1993, 2003).

The lack of obvious abrupt changes in maturity of the psammite, or size of the bedforms suggests that the multi-storey, nested geometry of the trough-cross bed units was formed by channels of relatively constant discharge, rather than channels of flashy and highly variable 
discharge (Skelly et al. 2003; Bridge 1993; Bluck 1976). Planar cross-bedded units orientated at high angles to the channel margins are interpreted as laterally accreting channel bars, but the rare preservation of such features supports the inference that the depositional setting was characterised by laterally shifting channels (Miall 1992; Bridge 2003). These channel facies, together with the broadly unimodal NW-NE palaeoflow are typical of deposition within a relatively distal, medium-to-low energy fluvial braidplain environment. Similar facies are widely published from both ancient (i.e. pre-Devonian land plant fluvial systems; e.g. Fedo and Cooper 1990) and modern distal braidplain deposits (e.g. the modern distal Himalayan-Siwalik system) (Fisher et al. 2007; Nichols and Fisher 2007; Kumar et al. 2007; Nakayama and Ulak 1999). Compared to LF1, proximal or medial braidplain settings would be expected to contain less mature sediment, larger cross-beds and coarser flow deposits (Plink-Bjorklund et al. 2005; Newell et al. 1999; Leeder 1999; Frostick and Steel 1993).

\subsection{LF2}

The development of more coarsening-upward packages within LF2 compared to LF1 indicates a distinct change to the depositional environment (Miall 1990; Plint and Walker 1992). Most likely, deposition began to take place in a lower-energy shallow marine, rather than non-marine environment. The coarsening-upward LF2 units could result from a wide variety of depositional environments, however, the prevalence of ripple structures in peliterich lithologies at the base of the LF2 units, and the presence of mud drapes within the upper trough cross-bed psammitic facies, suggest that the LF2 facies resulted from tidally influenced fluvial deposition within a very distal fluvial braidplain, or shoreline, setting (Yang et al. 2008; Allen and Fielding 2007; Fisher et al. 2007; Plint and Walker 1992; Roberts 2007; Schumm 1993). The psammitic channel facies within the fining-upward facies sequences, and at the top of the coarsening-upward units, is likely to represent fluvially influenced sediment input to the inferred shallow marine depositional setting along a braiddelta, where fluvial channels prograded out from a palaeo-shoreline (McPherson et al. 1987; Miall 1990; Plint and Walker 1992). The lack of terrestrial vegetation in the Neoproterozoic means that fluvial channels were not confined by vegetation as is the case in modern 
meandering river systems (Long 2006). As a result, Neoproterozoic shorelines would probably have been characterised by a distributary network of numerous laterally aggrading, low energy, shallow fluvial channels, many of which would have been active within a braiddelta at any one time (McPherson et al. 1987). This is reflected by the persistent repetition, laterally and vertically, of similar fining- and coarsening-upward units within the lower Glascarnoch Formation.

\subsection{LF3}

On a kilometre-scale, the repetitive, fining-upward and coarsening-upward packages of LF2 develop upward into the rhythmically interbedded pelitic and psammitic coarsening-up packages of LF3. The repetitive (centimetre-scale) alternation of pinstripe and flaser bedding in the basal parts of these LF3 packages is very characteristic of oscillatory current energy. On a larger-scale (metre-scale), the alternation of the pinstripe and flaser bed units, with thicker micaceous-psammitic beds, indicates oscillatory flow energy of a longer time period. This dual-scale of rhythmic bed bundling which typifies the c. $2.0 \mathrm{~km}$ thickness of LF3, is characteristic of tidally influenced, shallow-marine deposition where spring-neap tidal cycles are superimposed onto diurnal tides (Chakraborty and Sensarma 2008; Yang et al. 2008; Aspler et al. 1994; Plint and Walker 1992).

Flow reversal ripple forms and reactivation surfaces, together with the bimodal palaeoflow data are further evidence for reversals in flow current direction on a cm-scale throughout LF3 (Allen and Fielding 2007; Plint and Walker 1992). Lacustrine facies might display a bimodal palaeoflow, if, for example, there is wind-induced wave motion acting in opposition to other currents, but this would not produce the consistent, rhythmic bundling of lithologies and bedforms as observed in LF3 (Kempf et al. 2009; Yang et al. 2008; Martel and Gibling 1991; Rogers and Astin 1991). 
The wide, shallow, sharp-based tabular-cross beds in LF3, which locally occur with the flaser and pinstripe bedding at the base of the LF3 units, are very similar to overbank, sheet flow deposits within distal fluvial settings (Long 2006; Erikkson et al. 1998). However, the juxtaposition of these sharp-based tabular cross-beds with bundles of flaser and pinstripe bedding means they are more likely to represent storm-surge generated deposits (Plint and Walker 1992; Fisher et al. 2007), which is supported by the rare presence of hummocky stratified beds. The upward development of stacked multi-storey trough-cross beds towards the top of the coarsening-upward units suggests repeated returns to fluvially influenced deposition (Ghinassi et al. 2009; Plint and Walker 1992). Taken together, the LF3 facies are indicative of tidally-influenced shallow-marine deposition, above fair-weather base and close to a shoreline, with intermittent tidally influenced fluvial deposition.

\section{Soft-sediment deformation features}

Soft-sediment deformation features occur most commonly within the upper, finer lithofacies (LF2 and LF3), and very few are observed within the coarser, lower lithofacies (LF1). These features are invariably confined to individual beds and the tops of the deformation features are typically truncated by overlying beds. Seismic triggering of the deformation therefore seems unlikely, as a more random distribution of the features would be expected, as well as deformation of multiple beds. It is more likely that the soft-sediment deformation results from local depositional conditions, independent of seismic activity. The systematic decrease in amplitude and scale of deformation upward from bed base to bed top in many of the convoluted beds, indicates generation by fluid-escape following rapid sediment deposition in waterlogged sediment (see Maltman 1994; Nicholson 1993). Fluid escape can happen at any time in the unstable, and over-pressurised water-laden sediment - e.g. during a flood event. Slump folds, the other main type of soft-sediment deformation feature, are also largely contained to individual beds. Flows of unconsolidated, water-laden sediment can occur on any slope in a variety of settings. However, the apparent preferred orientation to the slump folds, so that the fold hinges are normal to the dominant NW-NNE palaeoflow direction, does suggest that the flows reflect movement of the sediment down the depositional slope within the basin in the direction of the dominant palaeoflow. The upward increase in abundance of soft-sediment features therefore suggests an increase in palaeoslope in the direction of 
palaeoflow within the shallow-marine depositional environment, compared to the distal braidplain environment.

\section{Sedimentological trends}

Taking into account the analysis of the lower Altnaharra Formation by Krabbendam et al. (2008), the complete vertical facies transition within the lower and middle Morar Groups is from: medium-energy fluvial braidplain deposition, characterised by large (metre-scale) trough-cross bedded psammite; to distal braidplain deposition, characterised by greater preservation of fines, smaller trough-cross beds and a greater preservation of lateral accretion features; to, finally, tide-dominated shallow-marine deposition, reflected by rhythmic bundles of interbedded pelitic and psammitic lithologies in the upper Glascarnoch Formation.

Collectively, the facies are evidence for a transition from a fluvial braidplain to tidally influenced shallow-marine depositional setting within the middle part of the Morar Group. This transition occurs gradually over a $c$. 4-6 km thickness (although tectonic strain means this is a maximum thickness). Within the same stratigraphic interval, palaeocurrent data indicate current patterns developed gradually from broadly unimodal NW-NNE directed flow at the base of the succession, to bimodal NW-SE flow at the top.

There are significant lateral lithofacies variations. Within the upper Altnaharra Formation, LF1 passes laterally eastward in to LF3, and similarly within the Glascarnoch Formation LF2 passes laterally eastward in to LF3 (Fig. 11). There is, therefore, an upward and eastward predominance of the finer and more complex shallow-marine lithofacies. These variations correspond to an apparent eastward thinning of the Altnaharra Formation (LF1), whilst the Glascarnoch Formation (LF2 and LF3) thickens eastward by c. 2 to $3 \mathrm{~km}$, over a distance of c. $20 \mathrm{~km}$ (Fig. 11).

\section{[Figure 11]}




\subsection{Discussion}

\subsection{Basin models for the Moine Supergroup}

The thick and laterally extensive siliciclastic units of the Altnaharra and Glascarnoch formations are characterised by sedimentary facies that are diagnostic of a large scale fluviomarine basin. The upward stratigraphic transition in depositional setting from medial braidplain to shallow-marine most likely reflects a gradual increase in the rate of generation of accommodation space as a result of tectonic subsidence, as well as the vertical superposition of increasingly distal facies. The general uniformity of sediment composition indicates that the rate of change of sediment flux in the basin was slight. This contrasts with the findings of Glendinning (1988) who interpreted the Upper Morar Psammite in Ardnamurchan and Morar (c.120 km south of the present study area, Figure 2) as a shallow marine deposit that accumulated in an active half-graben. However, the Altnaharra and Glascarnoch Formations lack the hallmark features of rift-basin successions: there is no evidence for the episodic emplacement of fault-generated detritus (all facies and lithogical transitions are very gradual); there is no evidence for abrupt, periodic (i.e. repetitive) generation of accommodation space that would be expected along basin-bounding faults; nor are there any abrupt vertical or lateral facies transitions which are characteristic of rift-basin settings (e.g. Arche and Lopez-Gomez 2005). Over c. 4-6 km of stratigraphy there is no indication of volcanic input, no coarse-grained deposits or rapid changes to the dominant palaeoflow direction, which is atypical of rift basin settings (e.g. Allen and Allen 2005). Essentially the same conclusions were reached by Bonsor \& Prave (2008) in their reappraisal of the Upper Morar Psammite in Ardnamurchan as a medium-energy fluvial braidplain deposit that accumulated in a large-scale basin.

\subsection{Regional correlations}

The early Neoproterozoic Torridon Group outcrops extensively on the Caledonian foreland in northern Scotland, west of the Moine Thrust Zone (Stewart 2002 and references therein). The possibility of correlation of the Torridon Group and the Moine Supergroup has been discussed frequently (e.g. Peach et al. 1907; Kennedy 1951; Sutton \& Watson 1964; Stewart 2002; Friend et al. 2003), although has often been discounted because of the potentially large displacements that may have occurred along the intervening Moine Thrust. The most recent 
comparison of stratigraphy, sedimentology, geochemistry and detrital zircon data, however, favours correlation of the lower Altnaharra Formation (lowermost Morar group) and the Applecross Formation of the Torridon Group in Sutherland (Krabbendam et al. 2008). Both are interpreted as fluvial braidplain deposits that accumulated in the foreland basin to the developing Grenville Orogen. The findings of the present study are consistent with this model. Interestingly, it is now apparent that both the Morar and Torridon groups are characterised by major fining-upwards trends. In the Morar Group, the present study demonstrates a fluvial to marine transition, whereas in the Torridon Group the facies change is from fluvial to lacustrine (Stewart 2002).

\subsection{Tectonic setting}

The Torridon and Morar basin is envisaged by Rainbird et al. (2001), Kinnaird et al. (2007) and Krabbendam et al. (2008) as an elongate, orogen-parallel foreland basin in front of the Grenville orogen. In a recent tectonic reconstruction, Cawood et al. (2010) suggested a clockwise rotation of Baltica away from Laurentia after $1250 \mathrm{Ma}$, creating a large triangular basin, the Asgard Sea, coeval with Grenville orogenesis farther south (present-day coordinates) (Fig 1b). The apex of the Asgard Sea would have been positioned close to Scotland, whilst farther north, facing northern Greenland and Scandinavia, the Asgard Sea was probably floored by oceanic crust. This reconstruction would imply that north of Scotland there was a large basin into which sediment, derived from the Grenville orogen, was routed. Thus there must have been a transition from a continental foreland basin to a marine basin; a transition that could have changed location with time, as both the Grenville orogen and the Asgard Sea developed. In the context of the present paper, this is attractive, in that the Torridon and lowermost Morar groups could represent the (orogen-parallel) foreland part, whilst the middle Morar group as reported here could represent the transition into the marine basin. This is consistent with the predominantly eastward palaeocurrents reported from the Torridon Group and lowermost Morar Group (Nicholson 1993; Stewart 2002; Krabbendam et al. 2008) and the northerly palaeocurrents reported higher up in the sequence in this study and in Bonsor \& Prave (2008). Furthermore, it provides a good explanation for sediment flux to the Krummedal sequence in NE Greenland and other early Neoproterozoic sequences in Svalbard and Caledonide allcohthons in northern Norway. These siliciclastic (now metamorphosed) sequences were deposited at c. 1000 and contain detrital zircon distributions 
similar to the Morar Group, and ultimately mainly derived from the Grenville orogen (Strachan et al. 1995; Watt et al. 2001; Cawood et al. 2007, 2010; Kirkland et al. 2008; Pettersson et al. 2009).

\subsection{Conclusions}

New sedimentological data from the Altnaharra and Glascarnoch Formations provides evidence for a large-scale transition from distal fluvial braidplain to shallow-marine, tidally influenced, deposition over a c. $6 \mathrm{~km}$ stratigraphic thickness in the middle Morar Group (lower Moine Supergroup) in northern Scotland. Amalgamated and multi-storey sets of trough and tabular cross-bedding, with associated planar cross-bedding, define channel forms that characterise the lowest parts of the stratigraphy, whilst finer and more complex coarsening-upward packages of rhythmically interbedded pelitic and psammitic lithologies typify the uppermost stratigraphic sections. Lateral and vertical changes between the lithofacies are gradual and accompanied by a concomitant upward transition in palaeoflow direction from broadly unimodel NW-NNE flow, to weakly bimodal NW-SE flow. The facies succession is inferred to be the result of vertical superposition of increasingly distal shallow-marine, tidally influenced facies, over medial to distal braidplain facies. Such a gradual large-scale transition in depositional environment, suggests a large basinal setting, inconsistent with an episodic extensional rift-basin interpretation. Instead, we suggest that, deposition occurred in a transition between a foreland basin to the Grenville orogen and a marine basin associated with the Asgard Sea between Baltica and Laurentia.

\section{Acknowledgements}

This paper is published with the permission of the Director of the British Geological Survey (Natural Environment Research Council). Brian McIntyre is thanked for his assistance with photographic work.

\subsection{References}


Allen, J.P.,Fielding, C.R., 2007. Sedimentology and stratigraphic architecture of the Late Permian Betts Creek Beds, Queensland, Australia. Sedimentary Geology 202, 5-34.

Allen, J.R., 1985. Principles of physical sedimentology, Blackwell, London.

Allen, P.A.,Allen, J.R., 2005. Basin analysis: Principles and applications, Blackwell Publishing, London, $560 \mathrm{pp}$.

Arche, A.,López-Gómez, J., 2005. Sudden changes in fluvial style across the Permian?Triassic boundary in the eastern Iberian Ranges, Spain: Analysis of possible causes,. Palaeogeography, Palaeoclimatology, Palaeoecology 229, 104-126.

Aspler, L.B., Chiarenzelli, J.R.,Bursey, T.L., 1994. Ripple marks in quartz-arenites of the Hurwitz Group, Northwest Territories, Canada: Evidence for sedimentation in a vast, early Proterozoic, shallow, fresh-water lake,. Journal of Sedimentary Research A64 P2, 282-298.

Bluck, B.J., 1976. Sedimentation in some Scottish Rivers of low sinuosity. Transactions of the Royal Society, Edinburgh 69, 425-456.

Bonsor, H.C.,Prave, A.R., 2008. The Upper Morar Psammite of the Moine Supergroup, Ardnamurchan Peninsula, Scotland: depositional setting, tectonic implications. Scottish Journal of Geology 44, 1-12.

Bridge, J.S., 1993. The interaction between channel geometry, water flow, sediment transport and deposition in braided rivers. In: J.L. Best and C.S. Bristow (Eds), Braided Rivers. Geological Society, London, Special Publication, 75, 13-71.

Bridge, J.S., 2003. Rivers and floodplains: forms, processes and sedimentary record, Blackwell, London, $504 \mathrm{pp}$.

British Geological Survey, 2007. Bedrock Geology UK North, 1:625 000 scale. British Geological Survey, Keyworth, Nottingham.

Cawood, P., Nemchin, A.A., Strachan, R., Prave, T.,Krabbendam, M., 2007. Sedimentary basin and detrital zircon record along East Laurentia and Baltica during assembly and breakup of Rodinia. Journal of the Geological Society of London 164, 257-275.

Cawood, P.A., Strachan, R., Cutts, K., Kinny, P.D., Hand, M.,Pisarevsky, S., 2010. Neoproterozoic orogeny along the margin of Rodinia: Valhalla orogen, North Atlantic. Geology 38, 99-102.

Chakraborty, T.,Sensarma, S., 2008. Shallow marine and coastal eolian quartz-arenites in the Neoarchean-Palaeoproterozoic Karutola Formation, Dongargarh Volcano-sedimentary succession, central India. Precambrian Research 162, 284-301.

Cutts, K.A., Kinny, P.D., Strachan, R.A., Hand, M., Kelsey, D.E., Emery, M., Friend, C.R.L.,Leslie, A.G., 2010. Three metamorphic events recorded in a signle garnet: Integrated pahse modelling, in situ LA_ICPMS and SIMS geochronology from the Moine Supergroup, NW Scotland. Journal of Metamorphic Geology.

Dalziel, I.W.D.,Soper, N.J., 2001. Neoproterozoic extension on the Scottish promontory of Laurentia: Paleogeographic and tectonic implications. Journal of Geology 109, 299-317.

Dalziel, I.W.D.,Soper, N.J., 2001. Neoproterozoic extension on the Scottish promontory of Laurentia: Paleogeographic and tectonic implications. Journal of Geology 109, 299-317. 
Eriksson, G., Condie, K.C., Tirsgaard, H., Mueller, W.U., Altermann, W., Miall, A., Aspler, L.B., Catuneanu, O.,Chiarenzelli, J.R., 1998. Precambrian clastic sedimentation systems. Sedimentary Geology 120, 5-53.

Fedo, C.M.,Cooper, J.D., 1990. Braided fluvial to marine transition: the basal Lower Cambrian Wood Canyon Formation, southern Marble Mountains, Mojave Desert, California. Journal of Sedimentary Petrology 60, 220-234.

Fisher, J.A., Nicols, G.J.,Waltham, D.A., 2007. Unconfined flow deposits in distal sectors of fluvial distributary systems: Examples from the Miocene Luna and Huesca systems, northern Spain. Sedimentary Geology 195, 55-73.

Friend, C.R.L., Strachan, R.A.,Kinny, P.D., 2008. U-Pb zircon dating of basement inliers within the Moine Supergroup, Scottish Caledonides: implications of Archaean protolith ages. Journal of the Geological Society of London 165, $807-815$.

Friend, C.R.L., Strachan, R.A., Kinny, P.D.,Watt, G.R., 2003. Provenance of the Moine Supergroup of NW Scotland; evidence from geochronology of detrital and inherited zircons from (meta)sedimentary rocks, granites and migmatites. Journal of the Geological Society of London 160, 247-257.

Frostick, L.E.,Steel, R.J., 1993. Tectonic signatures in sedimentary basin fills: an overview In: L.E. Frostick and R.J. Steel (Eds), Tectonic controls and signatures in sedimentary successions. Special Publication of the International Association of Sedimentologists, 20, 1-13.

Ghinassi, M., Libsekal, Y., Papini, M.,Rook, L., 2009. Palaeoenvironments of the Buia Homo site: High resolution facies analysis and non-marine stratigraphy in the Alat formation (Pleistocene Dandiero Basin, Danakil depression, Eritrea). Palaeogeography, Palaeoclimatology, Palaeoecology 280, 415-431.

Glendinning, N.R.W., 1988. Sedimentary structures and sequences within a late Proterozoic tidal shelf deposit; the upper Morar Psammite Formation of northwestern Scotland. In: J.A. Winchester (Ed), Later Proterozoic stratigraphy of the Northern Atlantic Regions. Blackie, Glasgow and London, p17-31.

Hoffman, P.F., 1991. Did the Breakout of Laurentia turn Gondwanaland inside out? Science 252, 1409-1412.

Holdsworth, R.E., 1989. The geology and structural evolution of a Caledonian fold and ductile thrust zone, Kyle of Tongue region, Sutherland, northern Scotland. Journal of the Geological Society of London 146, 809-823.

Holdsworth, R.E., Strachan, R.A.,Harris, A.L., 1994. The Moine Supergroup. In: W. Gibbons and A.L. Harris (Eds), A Revised Correlation of Precambrian rocks in the British Isles. Geological Society of London Special Report, 22, 23-32.

Kempf, O., Blisniuk, P.M., Wang, S., Fang, X., Wrozyna, C.,Schwalb, A., 2009. Sedimentology, sedimentary petrology, and paleoecology of the monsoon-driven, fluvio-lacustrone Zhada Basin, SW-Tibet. Sedimentary Geology 222, 27-41.

Kennedy, W.Q., 1951. Sedimentary differentiation as a factor in the Moine-Torridonian correlation. Geological Magazine 88, 257-266.

Kinnaird, T.C., Prave, A., Kirkland, C.L., Horstwood, M., Parrish, R.,Batchelor, R.A., 2007. The late Mesoproterozoic-early Neoproterozoic tectonostratigraphic evolution of NW Scotland: the Torridonian revisited. Journal of the Geological Society of London 164, 541-551. 
Kirkland, C.L., Strachan, R.A.,Prave, A.R., 2008. Detrital zircon signature of the Moine Supergroup, Scotland: contrasts and comparisons with other Neoproterozoic successions within the circum-North Atlantic region. Precambrian Research 163, 332-250.

Kleinhaus, M.G., 2001. The key role of fluvial dunes in transport and deposition of sand-gravel mixtures, a preliminary note. Sedimentary Geology 143, 7-13.

Krabbendam, M., in press.

Krabbendam, M., Prave, A.P.,Cheer, D., 2008. A fluvial origin for the Neoproterozoic Morar Group, NW Scotland; implications for Torridon - Morar group correlation and the Grenville Orogen Foreland Basin. Journal of the Geological Society of London 165, 379-394.

Kumar, R., Suresh, N., Sangode, S.J.,Kumaravel, V., 2007. Evolution of the Quaternary alluvial LFn system in the Himalayan foreland basin: Implications for tectonic and climatic decoupling,. Quaternary Inernational 159, 6-20.

Leeder, M., 1999. Sedimentology and sedimentary basins: From turbulence to tectonics, Blackwell Science, 608 pp.

Li, Z.X., Bogdanova-Svetlana, V., Collins, A.S., Davidson, A., De Waele, B., Ernst, R.E., Fitzsimons, I.C.W., Fuck, A., Gladkochub, D.P., Jacobs, J., Karlstrom, K.E., Lu, S., Natapov, L.M., Pease, V., Pisaresvky, S.A., Thrane, K.,Vernikovsky, V., 2008. Assembly, configuration, and breakup history of Rodinia; a synthesis. Precambrian Research 150, 179-210.

Long, D.G.F., 2006. Architecture of pre-vegetation sandy-braided perennial and ephemeral river deposits in the Palaeoproterozoic Athabasca Group, northern Saskatchewan, Canada as indicators of Precambrian fluvial style. Sedimentary Geology 90, 71-95.

Maltman, A., 1994. Prelithification Deformation. In: P.L. Hancock (Ed), Continental Deformation. Pergamon Press, 143-158.

Martel, A.T.,Gibling, M.R., 1991. Wave-dominated lacustrine facies and tectonically controlled cyclicity in the Lower Carboniferous Horton Bluff Formation, Nova Scotia, Canada. In: P. Anadon, L. Cabera and K. Kelts (Eds), Lacustrine facies analysis. Special Publication of the International Association of Sedimentologists, 13, 199-221.

Martins-Neto, M. A. 2000. Tectonics and sedimentation in a paleo / mesoproterozoic rift-sag basin (Espinhaco Basin, southeastern Brazil), Precambrian Research 103, 147-173.

McPherson, J. G., Shanmugam, G. And Moiola, R. J. 1987. Fan-deltas and braid deltas: Varieties of coarse-grained deltas, GSA Bulletin 99, 3, 331-340.

Melchor, R. N. 2007. Changing lake dynamics and sequence stratigraphy of synrift lacustrine strata in a half graben: an example from the Triassic Ischigualasto-Villa Union Basin, Argentina, Sedimnetology 54, 1417-1446.

Miall, A., 1990. Principles of Sedimentary Basin Analysis, Springer-Verlag, New York, 616 pp.

Miall, A.D., 1992. Alluvial deposits. In: R.G. Walker and N.P. James (Eds), Facies models: a response to sea level change. GeoText1. Geological Association of Canada, St John's, 119142.

Nakayama, K.,Ulak, P.D., 1999. Evolution of fluvial style in the Siwalik Group in the foothills of the Nepal Himalaya. Sedimentary Geology 25, 205-224. 
Newell, A.J., Tverdokhlebov, V.P.,Benton, M.J., 1999. Interplay of tectonics and climate on a transverse fluvial system, Upper Permian, Southern Uralian Foreland Basin, Russia. Sedimentary Geology 127, 11-29.

Nichols, G.J.,Fischer, J.A., 2007. Processes, Facies and architecture of fluvial distributory deposits. Sedimentary Geology 195, 75-90.

Nicholson, P.G., 1993. A basin reappraisal of the Proterozoic Torridon Group, northwest Scotland. In: L.E. Frostick and R.J. Steel (Eds), Tectonic controls and signatures in sedimentary successions. International Association of Sedimentologists Special Publication 20, 183-202.

Peach, B.N., Horne, J., Gunn, W., Clough, C.T., Hinxman, L.W.,Teall, J.J.H., 1907. The geological structure of the North-West Highlands of Scotland. Memoirs of the Geological Survey of Great Britain, 668 pp.

Pettersson, C.H., Pease, V.,Frei, D., 2009. U-Pb zircon provenance of metasedimentary basement of the Northwestern Terrane, Svalbard: Implications for the Grenvillian-Sveconorwegian orogeny and development of Rodinia. Precambrian Research 175, 206-220.

Plink-Bjorklund, P., Bjorklund, L.,Loorents, K.J., 2005. Sedimentary documentation of the break-up of Rodinia, Offerdal Nappe, Swedish Caledonides. Precambrian Research 136, 1-26.

Plint, A.G.,Walker, R.G., 1992. Tidal Deposits. In: R.G. Walker and N.P. James (Eds), Facies Models: a response to sea level change. Geological Association of Canada, 220-230.

Rainbird, R.H., Hamilton, M.A.,Young, G.M., 2001. Detrital zircon geochronology and provenance of the Torridonian, NW Scotland. Journal of the Geological Society of London 158, 15-27.

Ramsay, J.G., 1958. Moine-Lewisian relations at Glenelg, Inverness-shire. Quarternary Journal of the Geological Society of London 113, 487-523.

Roberts, E.M., 2007. Facies architecture and depositional environments of the Upper Cretaceous Kaiparowits Formation, southern Utah. Sedimentary Geology 197, 207-233.

Rogers, D.A.,Astin, T.R., 1991. Ephemeral lakes, mud pellet dunes and wind-blown sand and silt: reinterpretations of Devonian lacustrine cycles in north Scotland. In: P. Anadon, L. Cabera and K. Kelts (Eds), Lacustrine facies analysis. Special Publication of the International Association of Sedimentologists, 13, 199-221.

Sadowski, G.R.,Bettencourt, J.S., 1996. Mesoproterozoic tectonic correlations between eastern Laurentia and the western border of the Amazon Craton. Precambrian Research 76, 213-227.

Schumm, S.A., 1993. River response to base-level change: Implications for sequence stratigraphy. Journal of Geology 101, 279-296.

Skelly, R.L., Bristow, C.S.,Ethridge, F.G., 2003. Architecture of channel-belt deposits in an aggrading shallow sandbed river: the lower Niobara River, northeast Nebraska. Sedimentary Geology $158,249-270$.

Soper, N.J., Harris, A.L.,Strachan, R.A., 1998. Tectonostratigraphy of the Moine Supergroup; a synthesis. Journal of the Geological Society of London 155 13-24.

Stewart, A.D., 2002. The Later Proterozoic Torridonian Rocks of Scotland: their Sedimentology, Geochemistry and Origin. Geological Society Memoir, 24, Geological Society of London, $130 \mathrm{pp}$. 
Strachan, R., Smith, M., Harris, A.L.,Fettes, D.J., 2002. The Northern Highland and Grampian terranes. In: N.H. Trewin (Ed), The Geology of Scotland. The Geological Society, London, $81-147$.

Strachan, R.A., 1986. Shallow-marine sedimentation in the Proterozoic Moine Succession, Northern Scotland. Precambrian Resources 32, 17-33.

Strachan, R.A., Holdsworth, R.E., Krabbendam, M.,Alsop, G.I., 2010. The Moine Supergroup of NW Scotland: insights into the analysis of polyorogenic supracrustal sequences. In: R. Law, R.W.H. Butler, R.E. Holdsworth, M. Krabbendam and R.A. Strachan (Eds), Continental Tectonics and Mountain Building: The Legacy of Peach and Horne. Geological Society. London, Special Publication 335, 231-252.

Strachan, R.A., Nutman, A.P.,Friderichsen, J.D., 1995. SHRIMP U-Pb geochronology and metamorphic history of the Smallefjord sequence, NE Greenland Caledonides. Journal Geological Society of London 152, 779-784.

Sutton, J.,Watson, J., 1964. Some aspects of Torridonian stratigraphy in Skye. Proceedings of the Geologists' Association 75, 251-289.

Watt, G.R.,Thrane, K., 2001. Early Neoproterozoic events in East Greenland. Precambrian Research $110,164-184$.

Yang, B.C., Gingras, M.K., Dalrymple, R.W.,Pemberton, S.G., 2008. Wave-generated tidal bundles as an indicator of wave-dominated tidal flats. Geology 36, 39 - 42. 
Tables

\begin{tabular}{|c|c|c|c|}
\hline Lithofacies & Main sedimentological features & Interpretation & Evidence \\
\hline LF1 & $\begin{array}{l}\text { Stacked, amalgamated trough-cross bed } \\
\text { sets, within fining-upwards sequences. } \\
\text { Planar cross-stratification bedforms rare; } \\
\text { no gravels. }\end{array}$ & $\begin{array}{l}\text { Low-energy distal fluvial } \\
\text { braidplain. }\end{array}$ & $\begin{array}{l}\text { The channel facies indicate lower energy, } \\
\text { laterally aggrading braided channels - } \\
\text { typical of distal braidplain environments. } \\
\text { Similar facies are observed in both ancient } \\
\text { (Fedo and Cooper 1990) and modern } \\
\text { distal braidplain deposits (Fisher et al. } \\
\text { 2007). }\end{array}$ \\
\hline LF2 & $\begin{array}{l}\text { Predominately planar cross-bedding } \\
\text { within fining and coarsening-upwards } \\
\text { sequences. Pelitic beds, mud drapes and } \\
\text { ripple-cross lamination increasingly } \\
\text { common stratigraphically upward. }\end{array}$ & $\begin{array}{l}\text { Distal braidplain-shoreline } \\
\text { setting; braid-delta. }\end{array}$ & $\begin{array}{l}\text { The tabular, planar bed geometry indicates } \\
\text { wide unconfined channels. The prevalence } \\
\text { of ripple structures and increased } \\
\text { preservation of mud drapes and pelite } \\
\text { suggests deposition occurred in a lower } \\
\text { energy environment. The mixture of } \\
\text { fining- and coarsening-upward trends, } \\
\text { concomitant with the increase in fines and } \\
\text { ripple structures, is characteristic of braid- } \\
\text { delta settings (McPherson et al. 1987). }\end{array}$ \\
\hline LF3 & $\begin{array}{l}\text { Decametre-scale coarsening-upward } \\
\text { sequences of rhythmically interbedded } \\
\text { pelitic and psammitic lithologies. Wide } \\
\text { range of ripple bedforms throughout. } \\
\text { Stacked and nested trough and tabular } \\
\text { cross-beds are common in sequence } \\
\text { tops. Flow reversal ripple forms, } \\
\text { indicate bidirectional currents. }\end{array}$ & $\begin{array}{l}\text { Shallow marine shoreline } \\
\text { environment }\end{array}$ & $\begin{array}{l}\text { The rhythmic interbedding of pinstripe } \\
\text { and flaser bedding and thicker planar } \\
\text { cross-beds is indicative of oscillatory } \\
\text { currents over varying time-scales. Such } \\
\text { flow conditions would not be expected } \\
\text { within a lacustrine environment (Roger } \\
\text { and Astin 1991; Yang et al. 2008; } \\
\text { Mertins-Neto 2000; Melchor 2007). Flow } \\
\text { reversal ripples, rare storm beds and } \\
\text { predominance of ripple bedforms support } \\
\text { a shallow-marine interpretation. }\end{array}$ \\
\hline
\end{tabular}




\section{Figures}
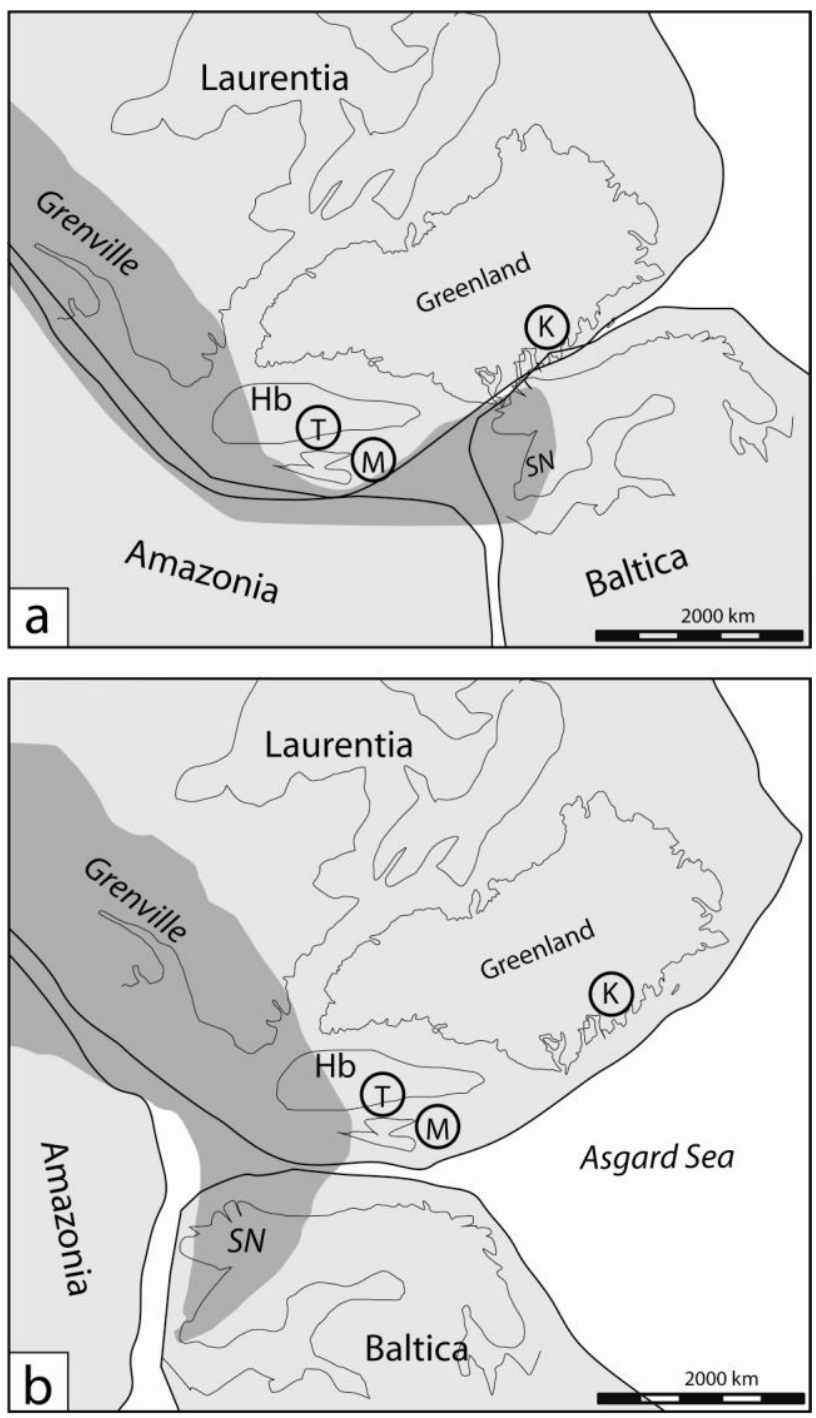

Figure 1. Schematic reconstructions of Laurentia, Baltica and Amazonia at c. 1000 Ma, following amalgamation of Rodinia and Grenville-age orogenesis: a) after Dalziel and Soper (2001); b) after Cawood et al. (2010). Approximate position of Morar (M), Torridon, (T) and Krummedal (K) sequences is indicated. $\mathrm{SN}=$ Sveconorwegian Belt; $\mathrm{Hb}=$ Hebridean block (NW Scottish Foreland and Rockall Platform). 


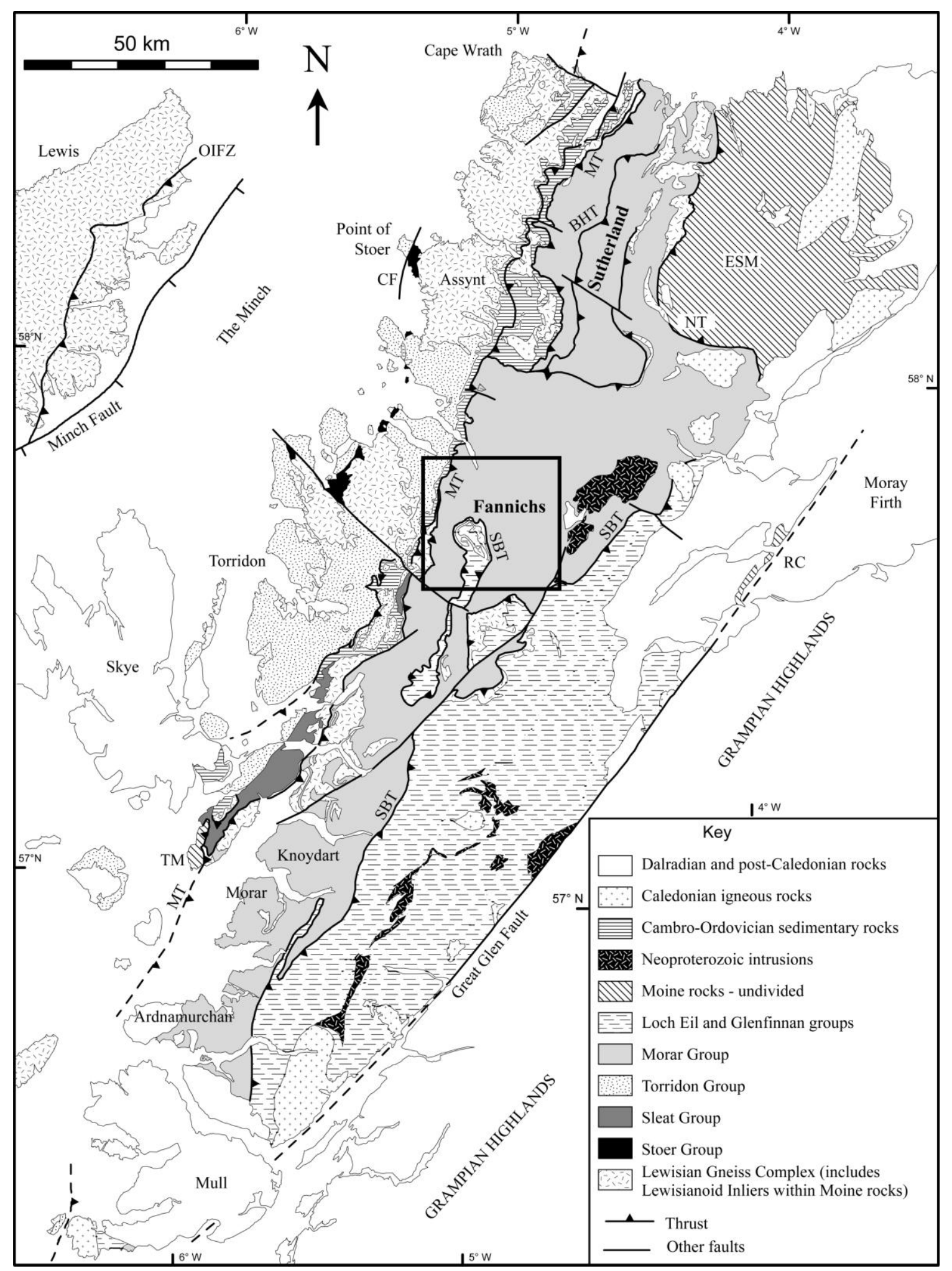

Fig. 2 - Geology of the Northern Highlands. Inset shows location of Figure 3. Modified after British Geological Survey (2007). abbreviations: BHT, Ben Hope Thrust; CF, Coigach Fault; OIFZ, Outer Isles Thrust Zone; MT, Moine Thrust; NT, Naver Thrust, SBT, Sgurr Beag Thrust; ESM, East Sutherland Moine; RC, RosemarkieCromarty Inliers; TM, Tarskavaig Moine. 


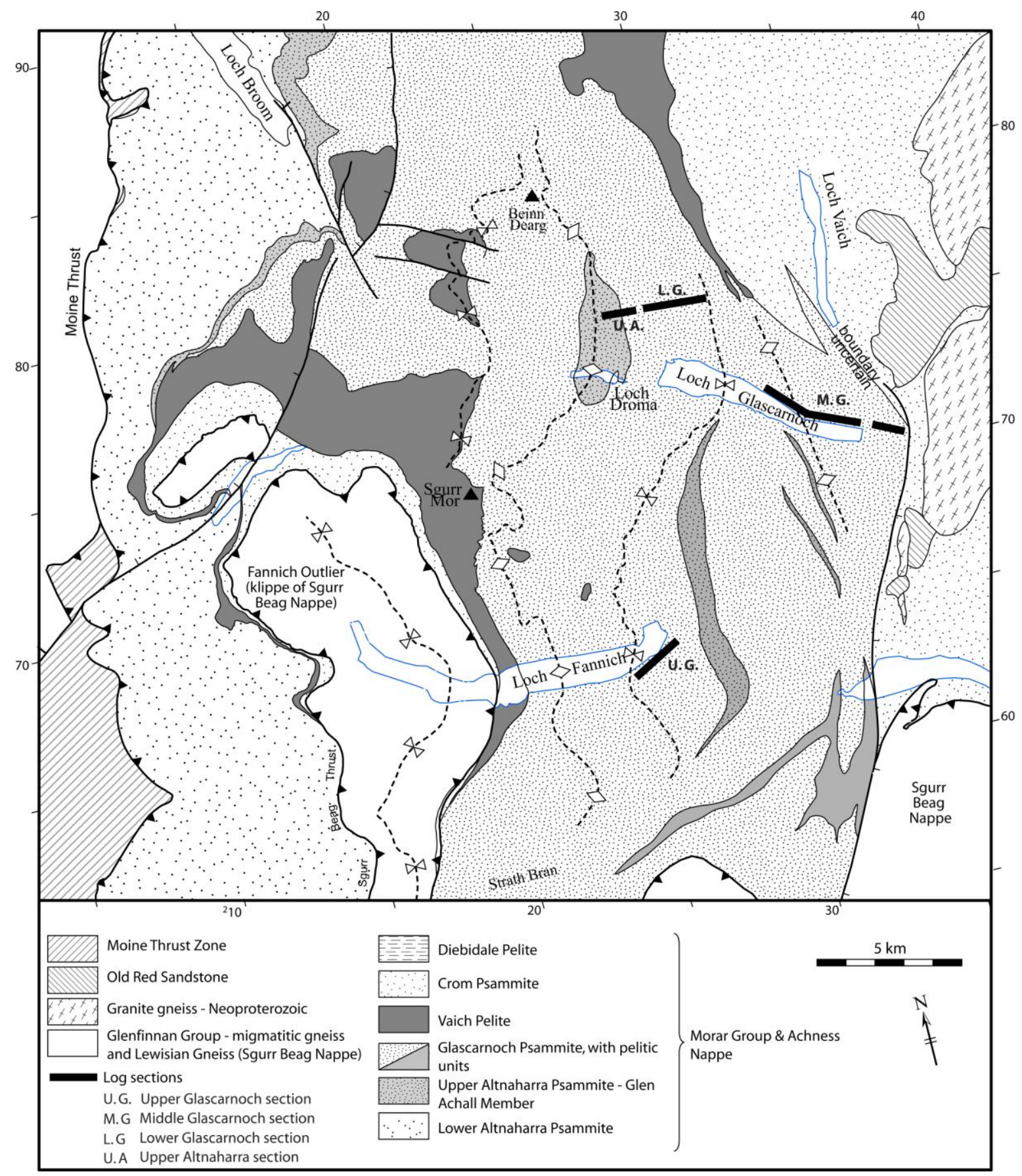

Fig. 3 - Geology of the Fannich mountains and surrounding area. 


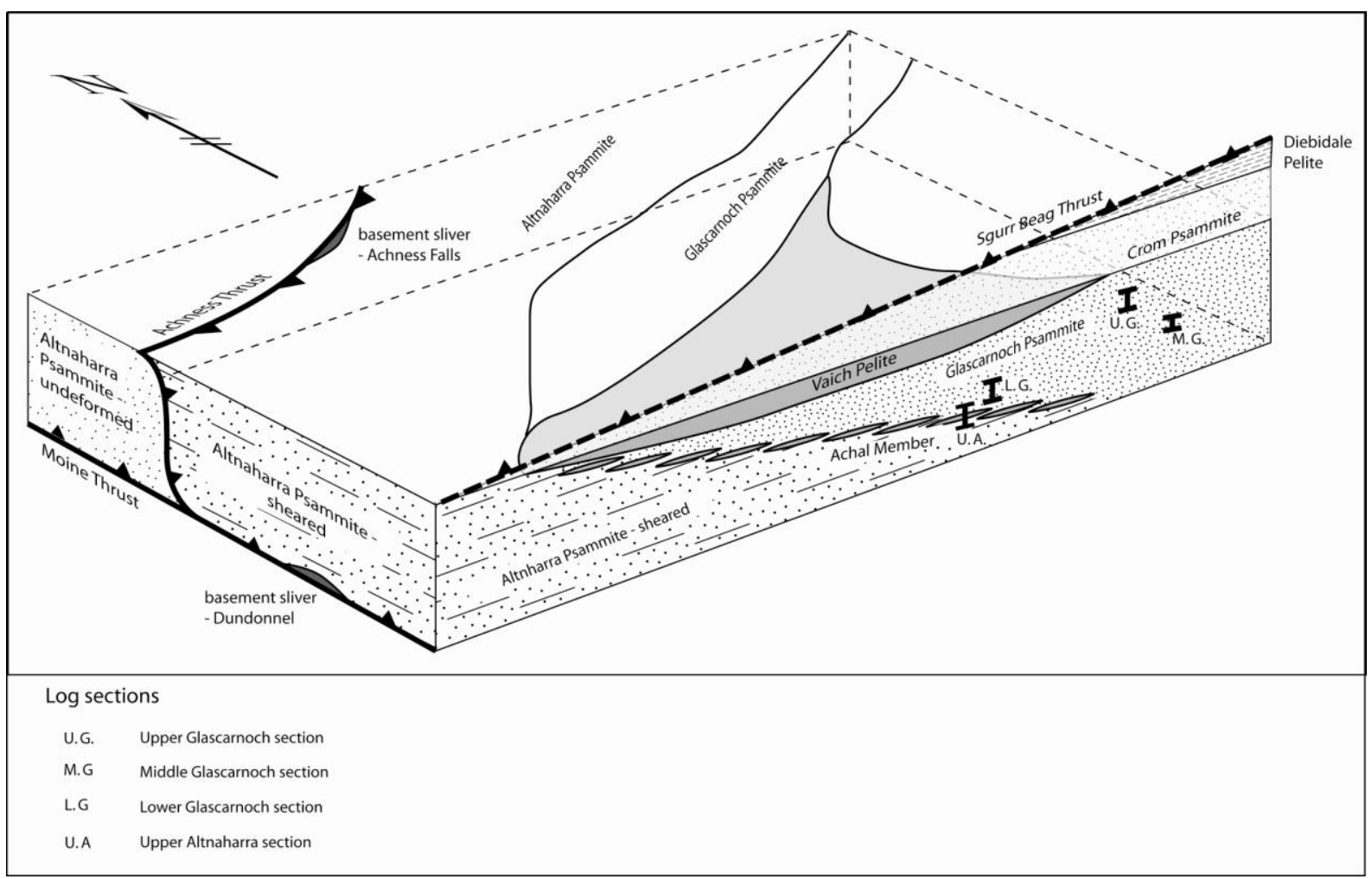

Fig. 4 - Reconstruction of the Morar Group stratigraphy within the Fannich Mountains, prior to large-scale Caledonian folding. Thick lines denote the stratigraphic position of log-sections. 


\section{Tectonostratigraphic Column}

Not to scale, but estimated thickness shown in metres

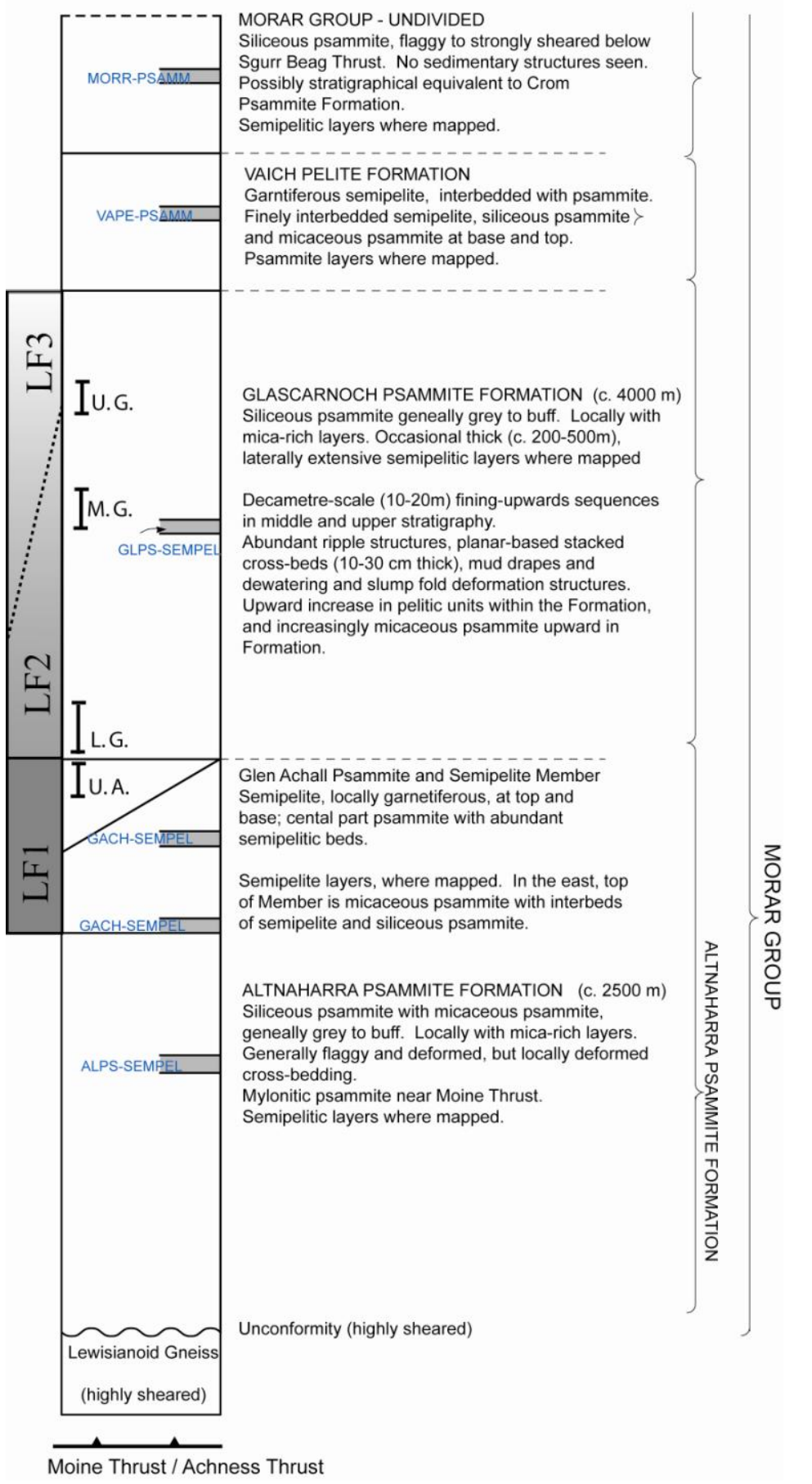

Fig. 5. Stratigraphic column for the Morar Group in the Fannich Mountains. The stratigraphic distribution of the observed lithofacies is marked to the left of the column. The bars denote approximate stratigraphic location and extent of the log sections, corresponding to the log sections marked in Figs. 3 and 4. 

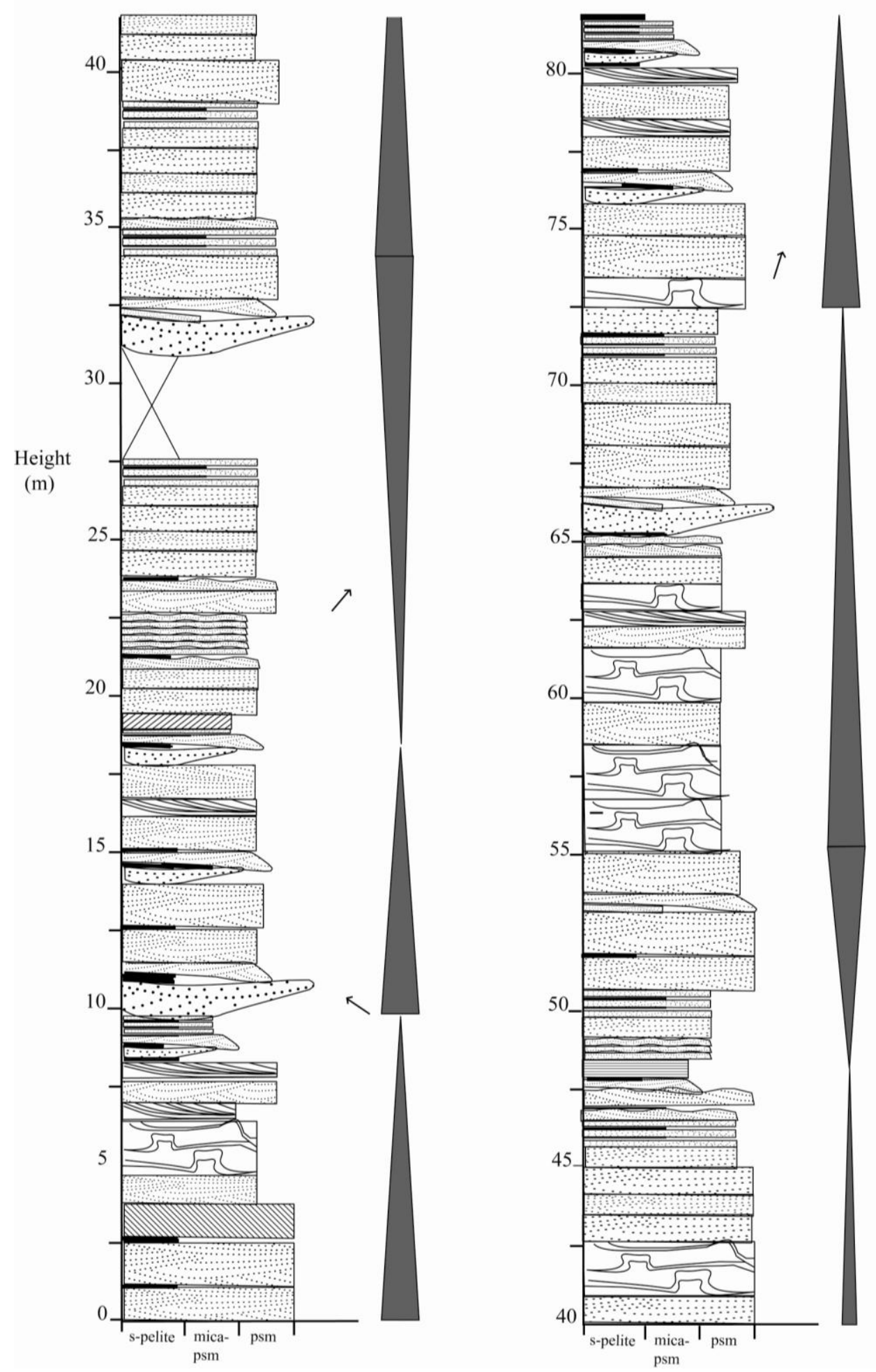

Fig. 6 - Sedimentological log (U.A.) of Upper Altnaharra Formation (Glen Achall Member), Fannich Mountains (GR 227062, 878299) - LF1. Arrows denote palaeoflow directions measured from trough cross-bed axes exposed in three-dimensions; pattern size denotes observed grain size - note no conglomerate. Grey triangles mark fining-upward and coarsening-upward units observed in LF1 
a

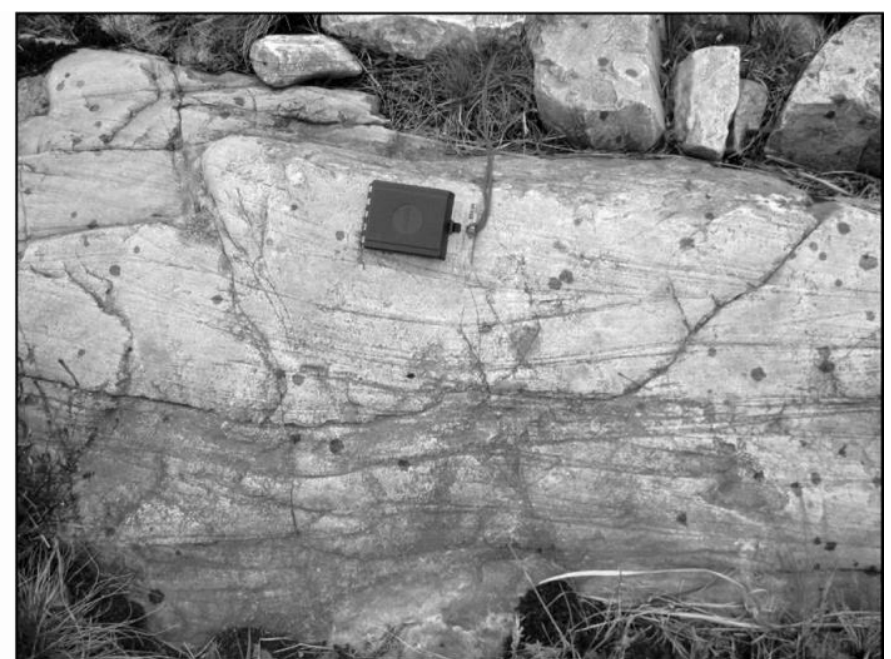

b

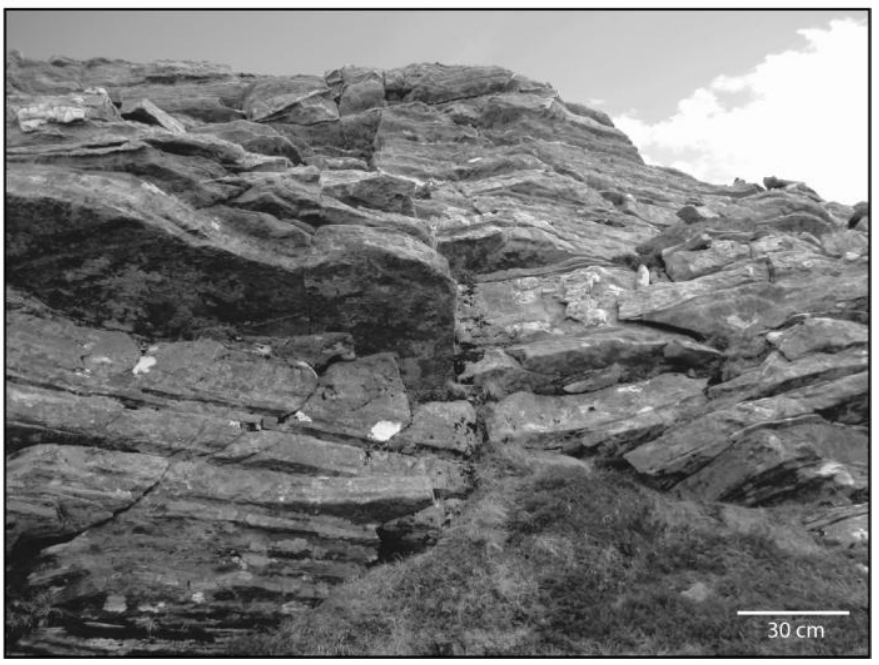

Fig. 7 - Photographs illustrating the LF2 lithofacies from log sections L.G. and M.G. within the Altnaharra and Glascarnoch Formations: (a) stacked sets of amalgamated trough-cross bed sets within LF2 (GR228544,8783908); and (b) decametre-scale coarsening-upward unit towards the top of LF2 (GR 234544, 8710278). 

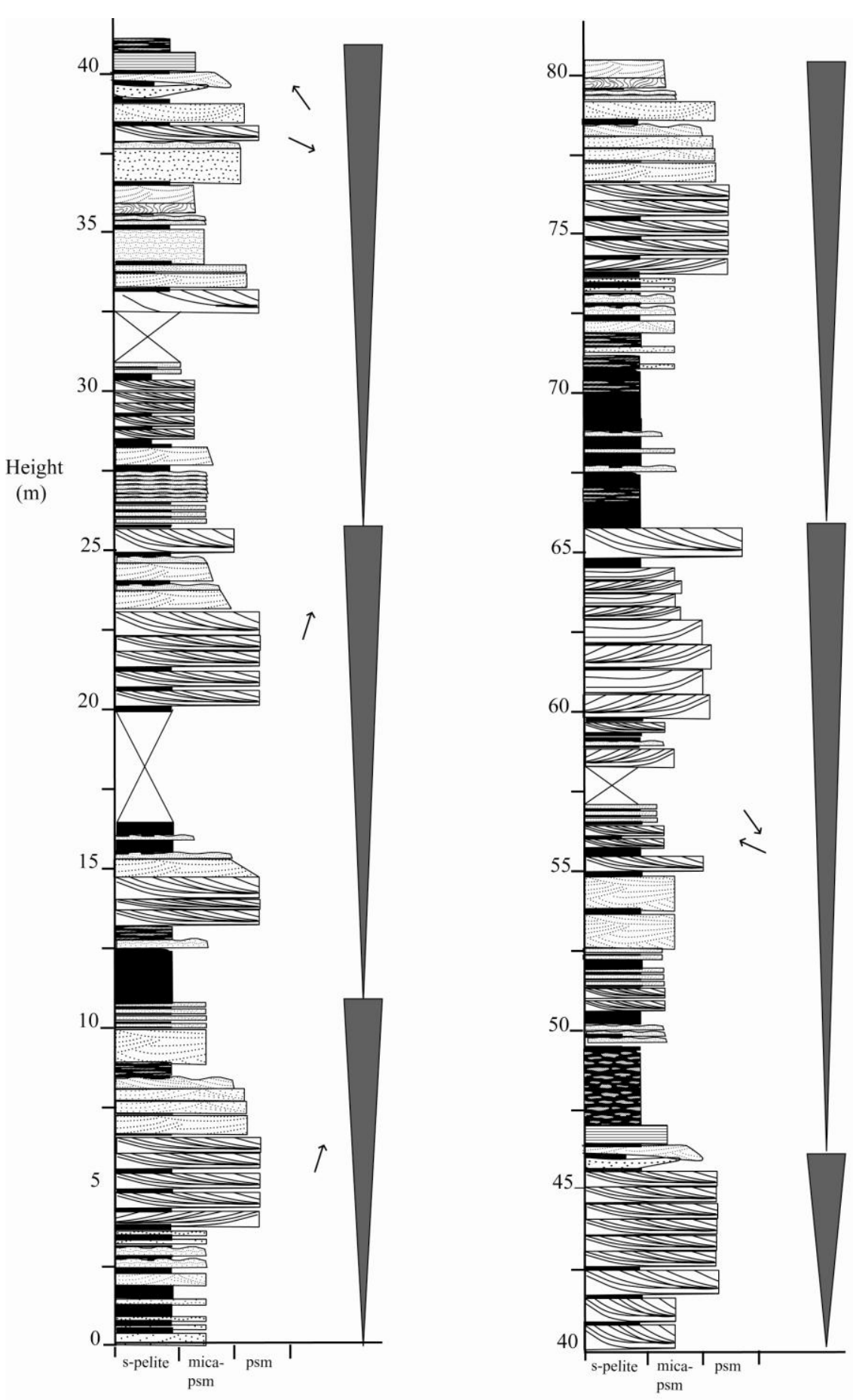

Fig. 8 - Sedimentological log (U.G.) of upper Glascarnoch Formation, Fannich Mountains (GR 226442, $865548)$ - LF3. Arrows denote palaeoflow directions measured from trough cross-bed axes exposed in threedimensions. Grey triangles mark coarsening-upward units observed in LF3. 
a

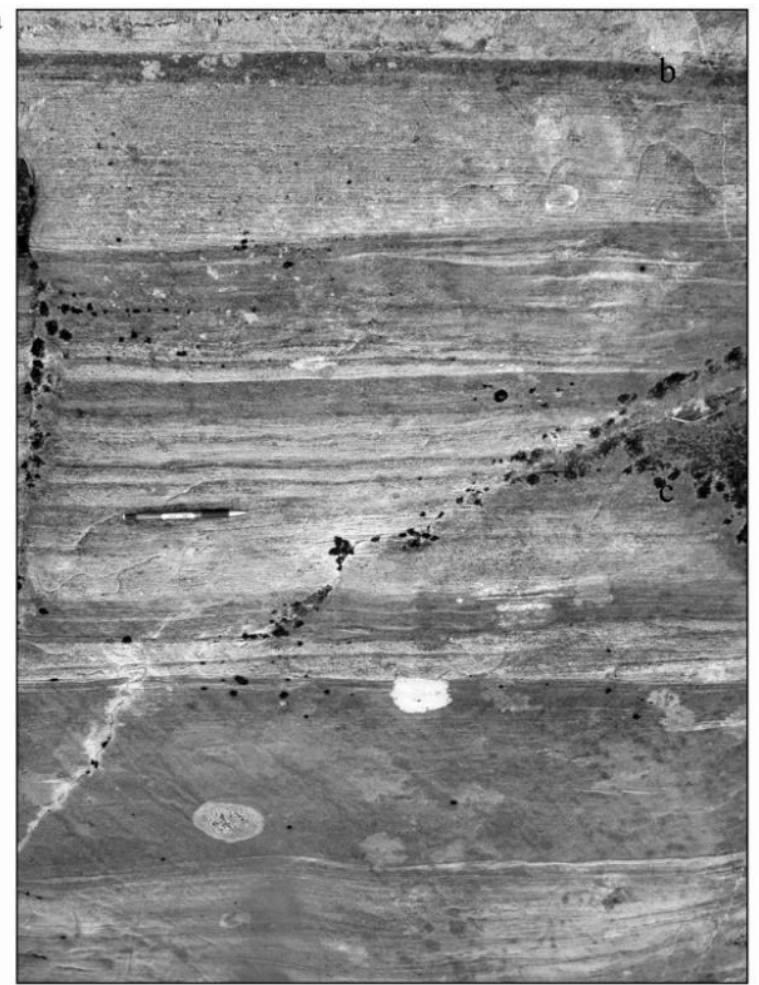

b

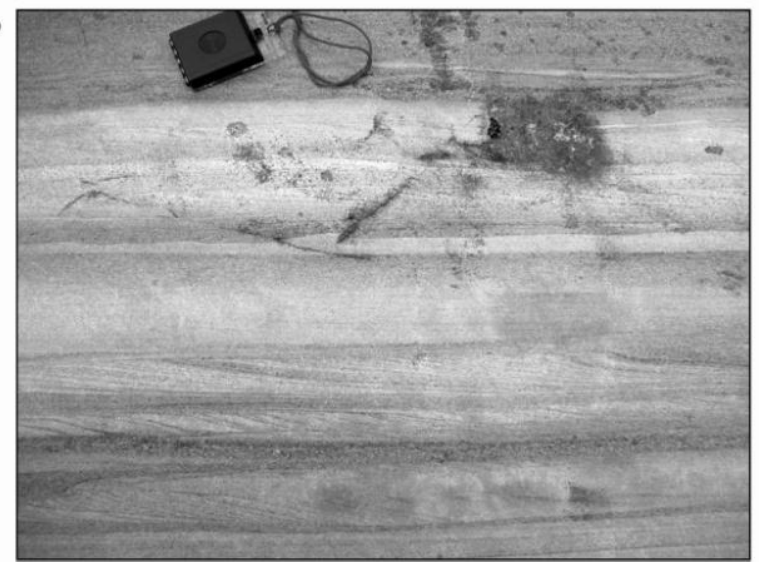

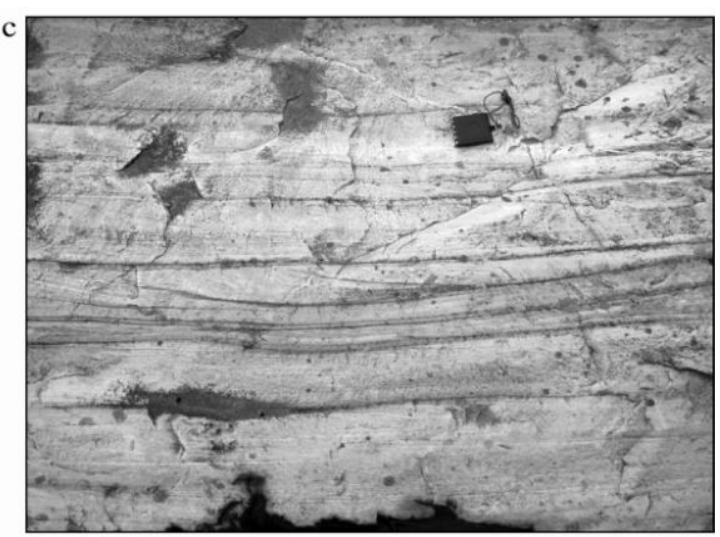
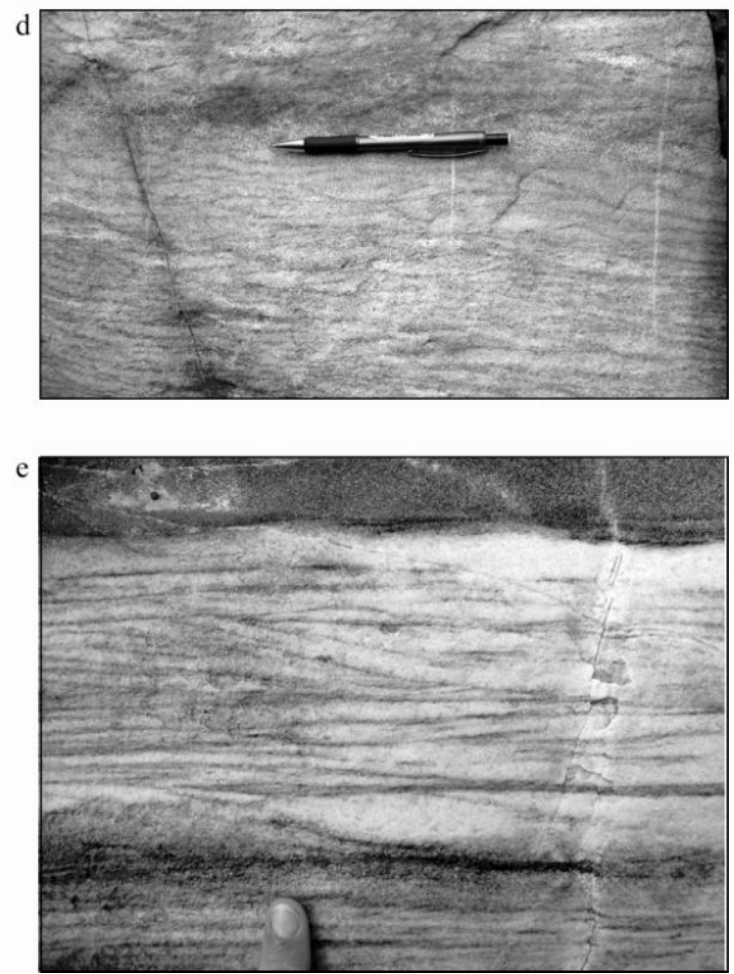

Fig. 9 - Photographs illustrating the LF3 lithofacies within the Glascarnoch Formation from log section U.G.: (a) rhythmic, repetitive bundling of pinstripe, wavy and flaser bedding (GR 226392, 865189); (b) rhythmic bundling of thick (up to $0.4 \mathrm{~m}$ thick) psammitic and micaeous-psammitic beds (GR 226155, 865500); (c) stacked and nested trough, and tabular cross-bed co-sets of micaeous-psammitic (GR 226358, 865653); (d) predominance of ripple structures and mud drapes on all bedforms in LF3; and (e) flow reversal ripple forms (GR 225957, 865189). Compass, for scale, is $5 \mathrm{~cm}$ wide. 


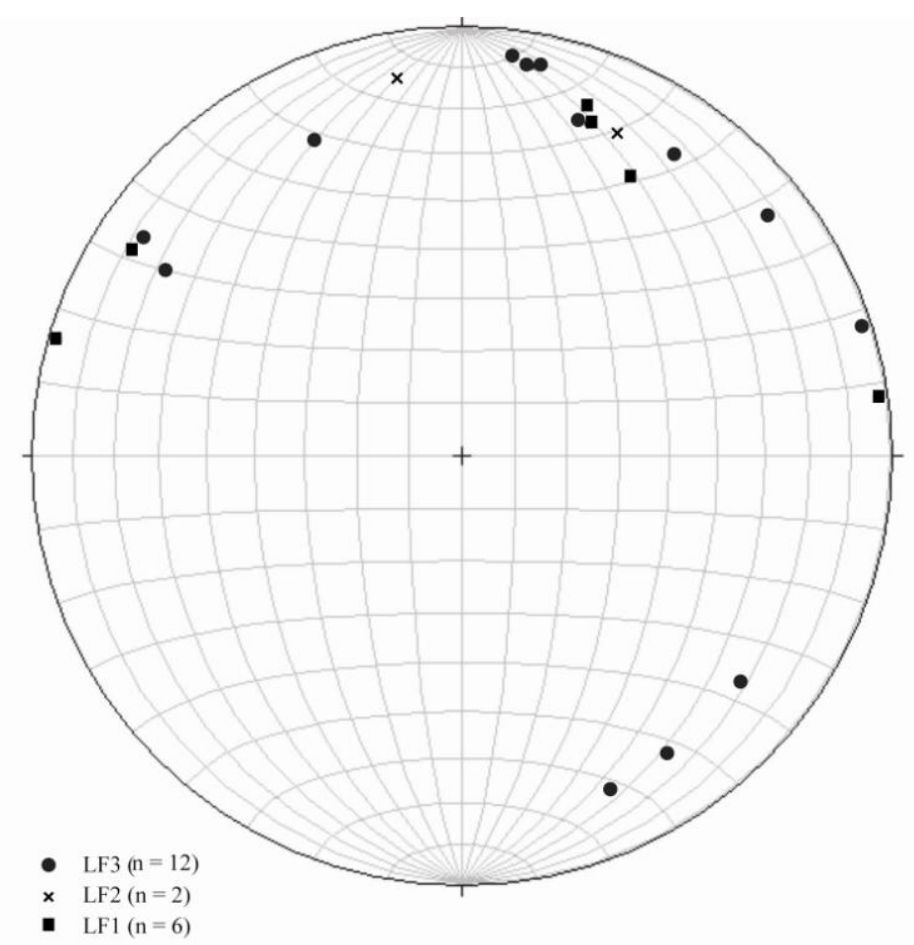

Fig.10 - Stereographic projection of palaeoflow direction measured in the three lithofacies. The poles plotted represent the azimuth and angle of palaeoslope determined. A gradual stratigraphic change in palaeoflow from unimodal NW-NE flow, to bimodal NW-SE flow is indicated. The range of directions within the NW-NE sector indicates the large variability of palaeoflow currents. 


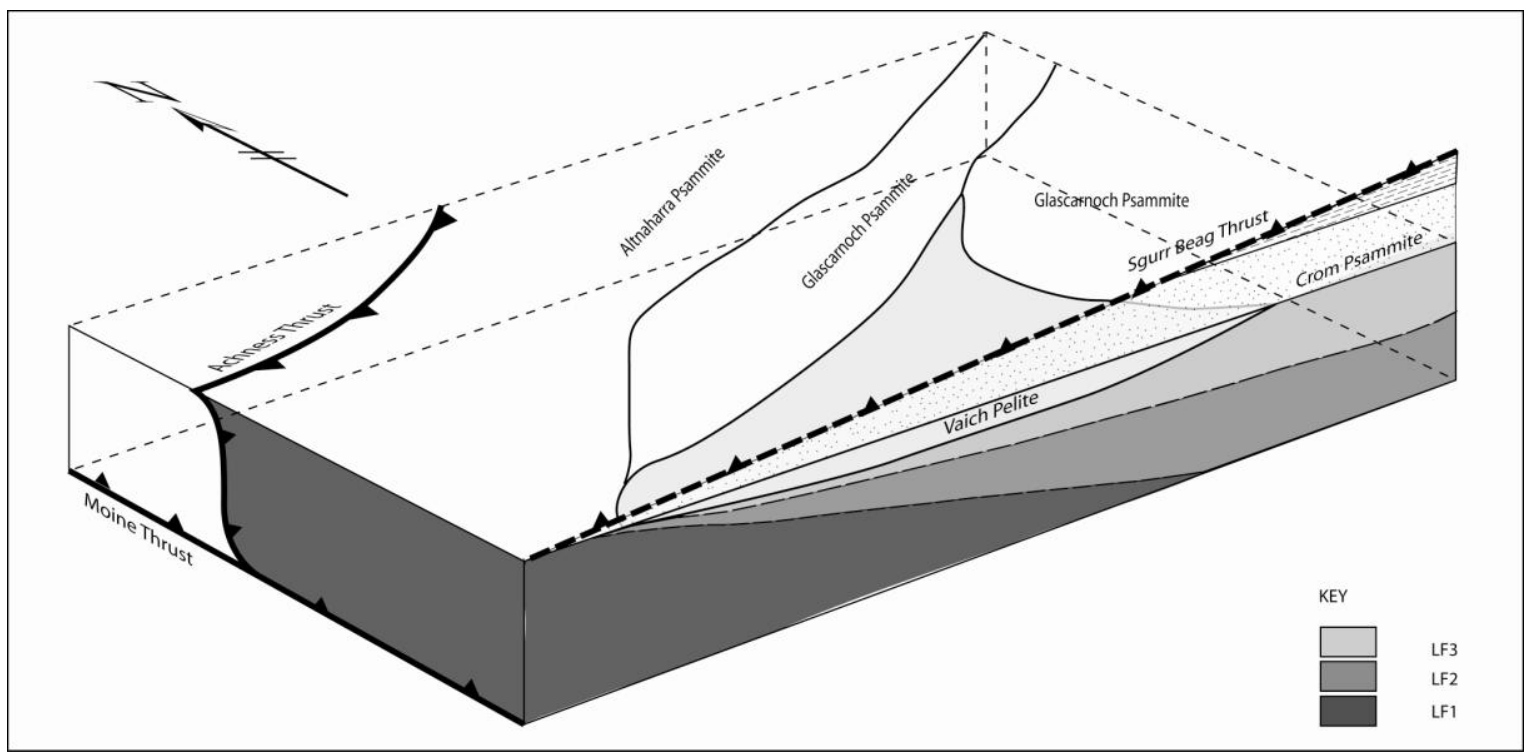

Fig. 11 - Block diagram of the Morar Group, in the Fannich Mountains as shown on Fig. 3, illustrating lateral variations in the distribution and thicknesses of lithofacies, and stratigraphic units. The main feature is an upward and eastward development of the finer-grained and more complex shallow-marine lithofacies within the Altnaharra and Glascarnoch formations. 